\title{
KKN TEMATIK DESA FATUSENE-KECAMATAN MIOMAFO TIMUR KABUPATEN TIMUR TENGAH UTARA
}

\author{
Dominggus G.H. Adoe ${ }^{1)}$, Jack C.A. Pah'1), Adi Y. Tobe ${ }^{1)}$ \\ 1)Program Studi Teknik Mesin, Fakultas Sains dan Teknik, Universitas Nusa Cendana, Kupang, NTT, Indonesia \\ Corresponding author : Dominggus G.H. Adoe \\ E-mail : godliefmesin@staf.undana.ac.id
}

\section{Diterima 26 Januari 2021, Drevisi 18 Februari 2021, Disetujui 21 Februari 2021}

\begin{abstract}
ABSTRAK
Kegiatan pengabdian pada masyarakat melalui Program Kuliah Kerja Nyata bertujuan untuk meningkatkan laju geraknya pembangunan masyarakat dengan menumbuh kembangkan motivasi pada masyarakat Desa Fatusene. Adapun target yang diharapkan dapat tercapai, yaitu : kebutuhan air bersih bagi masyarakat dapat terpenuhi, pembuatan kebun percontohan bagi masyarakat, mencegah hewan ternak terkena penyakit, mengajak anak-anak dan pemuda untuk menabung sejak dini, serta membuka pemahaman kepada masyarakat desa untuk melihat peluang usaha sehingga mereka tidak hanya bekerja sebagai petani tetapi juga mengelola hasil tani mereka menjadi produk jadi melalui usaha kecil maupun menengah. Metode pelaksanaan kegiatan ini adalah sosialisasi dan pelatihan dengan melibatkan masyarakat Desa Fatusene secara langsung. Beberapa hasil yang dicapai dalam kegiatan ini adalah tersedianya air bersih, hewan ternak yang tidak terkena penyakit, kebun percontohan yang dapat diikuti oleh masyarakat, terutama anak-anak dan remaja pada masyarakat Desa Fatusene, yang mulai menabung dan tumbuhnya jiwa kewirausahaannya.
\end{abstract}

Kata kunci: pengabdian masyarakat; KKN, pelatihan; sosialisasi

\begin{abstract}
Community service activities through the Community Service Program aim to increase the pace of community development by fostering and developing motivation in the people of Fatusene Village. The targets are expected to be achieved, namely: the need for clean water for the community can be met, making demonstration gardens for the community, preventing livestock from getting sick, inviting children and youth to save from an early age, and opening understanding to the village community to see business opportunities. So they not only work as farmers but also manage their agricultural products into finished products through small and medium enterprises. The method of implementing this activity is socialization and training by directly involving the Fatusene Village community. Some of the results achieved in this activity are the availability of clean water, livestock that are not affected by disease, demonstration gardens that can be followed by the community, especially children and adolescents in the community of Fatusene Village, who are starting to save and grow an entrepreneurial spirit.
\end{abstract}

Keywords: community service program; KKN; training; outreach

\section{PENDAHULUAN}

Kegiatan Kuliah Kerja Nyata (KKN)

Pembelajaran Pemberdayaan Masyarakat di Desa Fatusene, Kabupaten Timor Tengah Utara, Propinsi NTT, bertujuan untuk meningkatkan laju geraknya pembangunan masyarakat dengan menumbuh kembangkan motivasi pada masyarakat setempat. KKN ini dilakukan oleh mahasiswa Universitas Nusa Cendana (UNDANA) Kupang melalui Program dari Lembaga Pengabdian Pada Masyarakat (LPPM) UNDANA tahun 2019 (Dirjen Pendidikan Tinggi and Kebudayaan, 2013).

Desa Fatusene terletak di Kecamatan Miomafo Timur. Jarak tempuh dari pusat kota Kefamananu (Ibu Kota Kabupaten Timor
Tengah Utara) adalah $\pm 10 \mathrm{~km}$. Fatusene merupakan salah satu wilayah dari sebelas Ketemukungan yang ada di wilayah kekuasaan Kefetoran Tunbaba. Luas Desa Fatusene sekitar $5,33 \mathrm{~km}^{2}$. (Badan Pusat Statistik, 2015)

Penduduk Desa Fatusene mayoritas beragama katolik dan memiliki beragam pekerjaan pokok. Sebagian besar penduduknya sebagai petani/ peternak sebanyak 124 orang. Selain itu, juga terdapat 2 orang sebagai PNS (Pegawai Negeri Sipil), 3 orang pensiunan, 4 orang sebagai wirasuasta, 4 orang anggota TNI/ POLRI, 6 orang buruh, dll (Badan Pusat Statistik, 2018)

Batas-batas wilayah Desa Fatusene seperti Tabel 1. 
Tabel 1. Batas-batas wilayah Desa Fatusene

\begin{tabular}{|c|c|c|}
\hline Batas & Desa & Kecamatan \\
\hline $\begin{array}{c}\text { Sebelah } \\
\text { Utara }\end{array}$ & Tuntun & $\begin{array}{c}\text { Miomafo } \\
\text { Timur }\end{array}$ \\
\hline $\begin{array}{c}\text { Sebelah } \\
\text { Selatan }\end{array}$ & Amol & $\begin{array}{c}\text { Miomafo } \\
\text { Timur }\end{array}$ \\
\hline $\begin{array}{c}\text { Sebelah } \\
\text { Timur }\end{array}$ & Taekas & $\begin{array}{c}\text { Miomafo } \\
\text { Timur }\end{array}$ \\
\hline $\begin{array}{c}\text { Sebelah } \\
\text { Barat }\end{array}$ & $\begin{array}{c}\text { Kaenbaun } \\
\text { Dan Bitefa }\end{array}$ & $\begin{array}{c}\text { Miomafo } \\
\text { Timur }\end{array}$ \\
\hline
\end{tabular}

Berbagai permasalahan umum yang ada di masyarakat Desa Fatusene, sesuai dengan hasil observasi awal antara lain, persoalan air bersih dan sistem distribusinya (air bersih yang tidak menjangkau 2 dusun yang ada di Desa Fatusene), budaya bersih lingkungan yang masih kurang, cara berternak dan berrtani yang masih sangat tradisional, pelayanan kesehatan yang belum maksimal, kapasitas infrastruktur desa yang kurang memadai, penebangan atau penebasan lahan di sekitar sumber mata air, akses jalan menuju lahan pertanian belum tersedia, dll. Permasalahan-permasalahan ini umumnya disebabkan karena berbagai hal antara lain: keterbatasan Sumber Daya Manusia (SDM) di desa, keterbatasan modal usaha anggota kelompok masyarakat.

Pada sisi lain, berbagai macam permasalahan juga didorong oleh berbagai faktor lain seperti kebijakan manajemen Pemerintahan Daerah yang kurang tepat, kebijakan dan pemahaman konsep integrasi oleh SKPD, wakil rakyat dan instansi teknis terkait, serta masalah yang timbul kerena keadaan di luar kemampuan manusia seperti (Bencana Alam). Permasalahan-permasalahan yang ada ini, akan semakin besar manakala tidak pernah dilakukan identifikasi permasalahan yang sesuai, sumber penyebab masalahnya beserta tingkat signifikasinya tidak terukur, dan ketidakcermatan dalam mengidentifikasi dan memecahkan permasalahan yang sesuai dengan kebutuhan masyarakat. Hal-hal ini secara tidak langsung berdampak pada resiko pembiayaan anggaran dari berbagai program-progam yang dilaksanakan di desa ini (Dirjen Pendidikan Tinggi and Kebudayaan, 2013).

Oleh karena itu, Mahasiswa KKN Undana pada wilayah Kecamatan Miomafo Timur khususnya Desa Fatusene, merencanakan, menetapkan, dan menjalankan beberapa program kegiatan menjadi suatu paket aktualisasi program pembangunan sesuai situasi dan kondisi serta kebutuhan masyarakat. Program-program ini dipilih untuk dilakukan sebisa mungkin sesuai dengan akarakar penyebab timbulnya berbagai permasalahan pada masyarakat desa ini. Dengan demikian, seluruh aktivitas Mahasiswa dapat dirasakan sangat bermanfaat bagi Desa setempat.

\section{METODE}

Metode untuk mengatasi permasalahan yang ada di Desa Fatusene meliputi beberapa tahap, yaitu :

1) Persiapan dan pembekalan

Mekanisme pelaksanaan kegiatan KKN Tematik dilakukan melalui mekanisme sebagai berikut

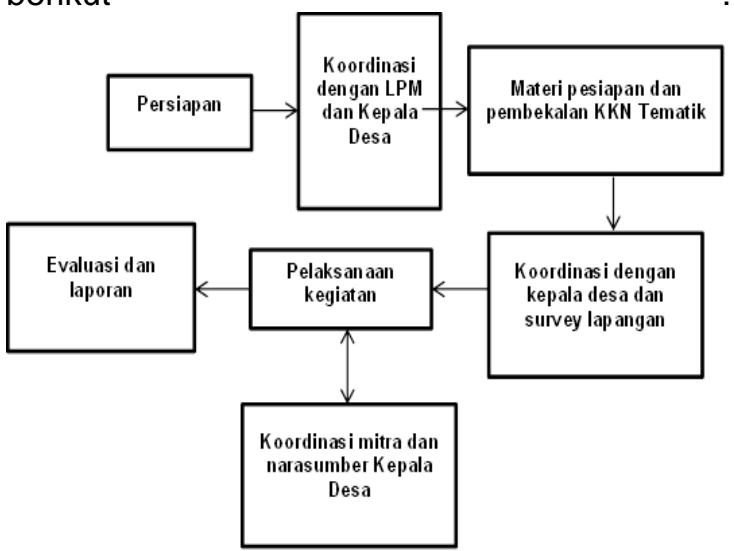

Gambar 1. Mekanisme pelaksanaan kegiatan

\section{2) Pelaksanaan}

Langkah-langkah yang akan dilaksanakan untuk mencapai hasil yang diharapkan dari tema KKN Tematik adalah :

a. Metode yang digunakan KKN Tematik di Desa Fatusene adalah Pendidikan dan pelatihan (diklat), diskusi, Demonstrasi/Percontohan dan Pendampingan serta Pembinaan berkelanjutan.

b. Langkah-langkah operasional yang diperlukan untuk memaksimalkan potensi wilayah Desa Fatusene dan mengatasi permasalahan yang dideskripsikan pada latar belakang, sebagai berikut :

- Penempatan mahasiswa KKN Tematik yang disebar secara merata ke tiap RT dan Kantor Desa menjadi Home Base untuk memudahkan koordinasi.

- Pengorganisasian masyarakat (Kelompok dan Masyarakat umum)

- Sebelum mahasiswa diterjunkan ke lokasi, tim DPL dan perwakilan mahasiswa terlebih dahulu ke lokasi untuk berdialog dengan aparat desa dan tokoh masyarakat, dengan harapan agar kelompok sasaran yang akan menerima program KKN Tematik sudah dapat ditentukan sebelum penerjunan mahasiswa, sehingga saat mahasiswa diterjunkan ke lokasi, masyarakat telah siap 
untuk bekerja bersama mahasiswa. Untuk mensukseskan kegiatan ini, masyarakat kemudian diberikan penyuluhan, percontohan dan pendampingan, kemudian bersama Masyarakat dan Aparat Desa melakukan evaluasi dan diskusi pembahasan masalah dan penetapan kegiatan bersama Mahasiswa KKN Tematik (Kemendes, 2019).

- Adapun Pelaksanaan kegiatan yang meliputi : pembersihan kapela dan tempat mata air, pembuatan kebun percontohan, pemberian vitamin pada ternak, penyuluhan tentang usaha kecil dan menengah bagi masyarakat desa Fatusene, pembuatan struktur desa, dan sosialisasi menabung dini bagi anak dan remaja Desa Fatusene.

\section{HASIL DAN PEMBAHASAN}

Kegiatan pengabdian masyarakat dimulai dengan mengobservasi lingkungan di Desa Fatusene oleh mahasiswa KKN. Setelah itu, mahasiswa KKN meminta izin pelaksanaan pada aparat desa, terkait kegiatan yang akan dilakukan. Adapun beberapa kegiatan yang dilakukan yaitu :

- Pembersihan pada sumber mata air dan saluran air. Menurut (Indarto, 2010) air adalah substansi yang paling melimpah dipermukaan bumi, komponen utama bagi semua makhluk hidup, dan merupakan kekuatan utama yang secara konstan membentuk permukaan bumi. Air juga merupakan faktor penentu dalam pengaturan iklim dipermukaan bumi untuk kebutuhan makhluk hidup. Aliran air dari sumber mata air (embung) di Desa Fatusene mengalami kemacetan karena kotoran yang menumpuk pada pipa aliran air. Hal ini disebabkan karena banyak kotoran yang menumpuk pada daerah sekitar mata air dan pada saluran air dari mata air. Mahasiswa KKN melakukan pembersihan di sekitar mata air dan saluran air (Gambar 2). Berbagai kotoran-kotoran baik kotoran organik dan unorganik dibersihkan dari sumber mata air dan saluran air. Disekitar mata air diberi perlindungan berupa pagar sederhana menggunakan potongan bambu dan lilitan kawat berduri. Pemasangan pipa untuk aliran air juga dilakukan untuk memperlancar aliran air. Persiapan alat dan bahan yang digunakan antara lain parang, selang, pipa, kunci dan ember, pemotongan bambu. Program ini bertujuan untuk membantu masyarakat memenuhi kebutuhan akan air bersih. Dengan adanya program ini maka air dapat mengalir sampai ke bak penampungan air utama, sehingga kebutuhan masyarakat akan air bersih dapat terpenuhi dan lebih higenis.

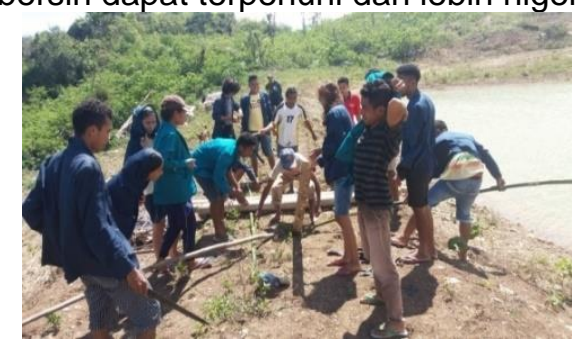

Gambar 2. Pembersihan Mata Air

Pembersihan kapela. Kapela merupakan tempat beribadah umat katolik masyarakat Desa Fatusene. Seperti telah disampaikan sebelumnya bahwa mayoritas penduduk desa ini beragama katolik. Dipilinnya kapela dalam kegiatan pembersihan ini, dikarenakan kapela adalah fasilatas utama peribadatan yang ada di desa ini, sehingga efek/ pengaruh positif dari kegiatan akan berimbas luas. Kegiatan ini memberikan pengaruh pada sikap masyarakat antara lain: Memberi edukasi dan contoh pada masyarakat tentang pentingnya kebersihan lingkungan, kebersihan lingkungan harus dilakukan bersama-sama dan menjadi tanggungjawab yang bersifat kolektif. Kegiatan ini dilakukan bersama masyarakat dan juga sekaligus menyiapkan kapela untuk peribadatan pada minggu itu. Kegiatan ini dilakukan pada tanggal 16 Juli 2019, seperti pada Gambar 3 berikut ini

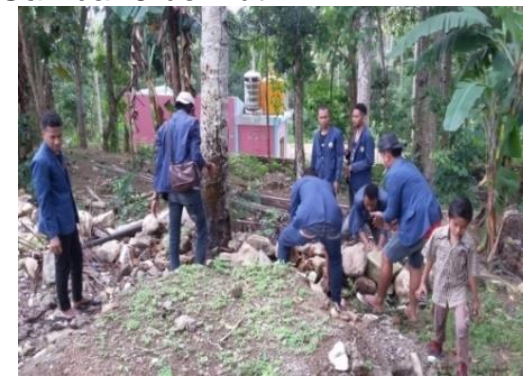

Gambar 3. Pembersihan Kapela

Pembuatan kebun percontohan. Kegiatan ini dilakukan 6 Agustus sampai 12 September 2019. Program ini dilakukan secara bertahap dengan rincian kegiatan sebagai berikut, persiapan alat dan bahan (parang, linggis) dan pembersihan lahan, penggemburan tanah, pembuatan bedeng, pemotongan bambu untuk pagar keliling bedeng, pembuatan pupuk bokashi dari kotoran sapi yang diambil dari kandang sapi milik warga. Bokashi merupakan salah satu jenis pupuk yang dapat menggantikan kehadiran pupuk kimia buatan untuk meningkatkan kesuburan tanah sekaligus memperbaiki kerusakan sifat-sifat tanah akibat pemakaian pupuk anorganik (kimia) secara berlebihan (Fitriany and Abidin, 2020). Pembuatan tempat persemayan anakan dan 
persemayan, dilanjutkan dengan penanaman anakan, penyiraman dan perawatan (Gambar 4). Dengan dilaksanakannya program ini maka diharapkan agar masyarakat dapat mengambil contoh sehingga mereka dapat memanfaatkan lahan di sekitar pekarangan rumah untuk bercocok tanam.

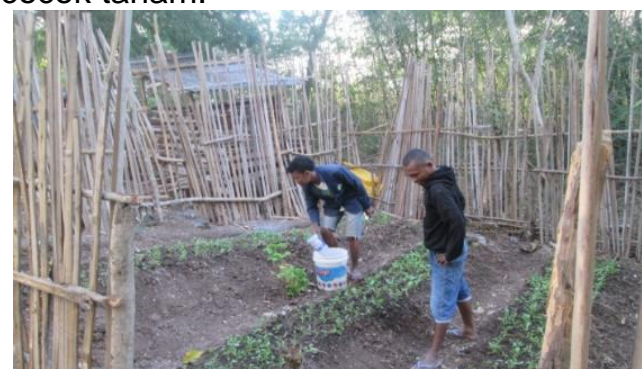

Gambar 4. Penyiraman Kebun Percontohan

- Pemberian vitamin pada ternak.

Kecenaan lemak merupakan indikasi pengangkut vitamin $A$ dan $E$ karena larut dalam lemak, sehingga kecenaan lemak diukur bersama dengan vitamin $A$ dan $E$. Vitamin A dan $E$ merupakan senyawa organik yang dibutuhkan dalam jumlah sedikit, vitamin A dan $E$ mempunyai fungsi dan peranan yang sangat besar terhadap produktivitas ayam (Sukamto, 2013). Berdasarkan hasil observasi menunjukkan bahwa ketika memasuki masa peralihan musim, banyak ternak ayam yang mati karena terkena penyakit. Oleh karena itu program pemberian vitamin pada ternak ayam ini dilakukan dengan tujuan menambah nafsu makan pada ternak dan meningkatkan daya tahan tubuh terhadap serangan penyakit. Kegiatan ini dilaksanakan mulai tanggal 13 Agustus 2019 hingga 26 Agustus 2019. Metode yang digunakan yakni praktek langsung dengan mencampurkan vitamin pada air minum dan selanjutnya diberikan pada (Gambar 5) ternak ayam milik warga Desa Fatusene. Media yang digunakan adalah air minum untuk ternak ayam, vitamin dan ternak ayam milik warga.

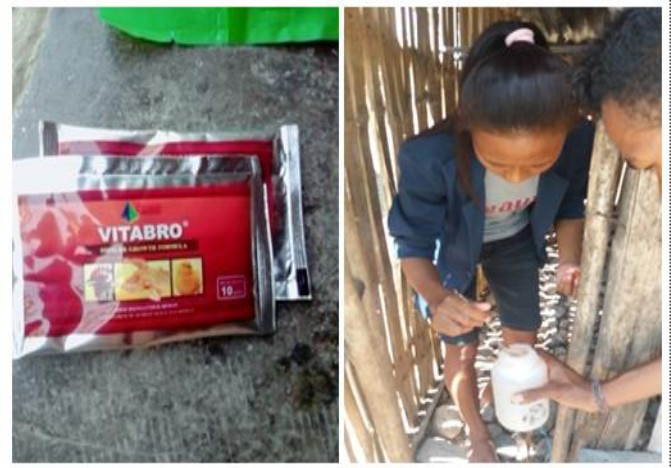

Gambar 5. Pemberian Vitamin pada Ternak
- Penyuluhan tentang usaha kecil dan menengah bagi masyarakat desa Fatusene. UKM adalah salah satu jenis usaha milik perorangan, badan usahanya tidak berbadan hukum atau badan usaha yang berbadan hukum. Badan usaha ini selain berdiri sendiri dan bukan merupakan anak perusahaan atau cabang perusahaan yang dimiliki, dikuasai, atau berafiliasi baik langsung maupun tidak langsung dengan usaha kecil, usaha menengah atau usaha besar (Munir, 2016). Berdasarkan hasil observasi yang dilakukan di desa Fatusene, ada beberapa masyarakat di desa yang sudah memiliki usaha yaitu kios dan berbagai usaha menengah yang didukung oleh koperasi desa. Namun masyarakat belum memahami dan mengetahui tentang bentuk usaha yang cocok dan layak yang mana dapat memberikan pendapatan lebih bagi rumah tangga mereka. Program ini bertujuan untuk membuka pemahaman kepada masyarakat desa untuk melihat peluang usaha sehingga mereka tidak hanya bekerja sebagai petani tetapi juga mengelola hasil tani mereka menjadi produk jadi melalui usaha kecil maupun menengah. Kegiatan ini dapat terlihat pada Gambar 6.

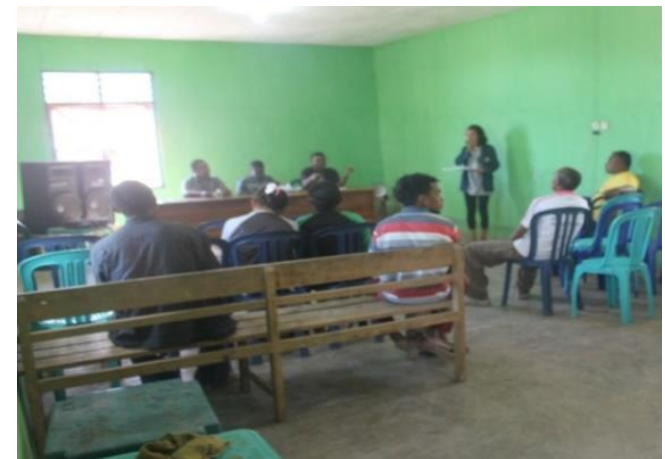

Gambar 6. Penyuluhan Tentang Usaha Kecil dan Menengah Bagi Masyarakat Desa Fatusene

Pembuatan peta desa dan struktur desa. Pembangunan di desa dapat diawali dengan inventarisasi potensi desa yang disajikan pada peta desa, merupakan peta tematik dasar yang berisi unsur dan informasi batas wilayah, infrastruktur transportasi, toponim, perairan, sarana prasarana, penutup lahan dan penggunaan lahan yang disajikan dalam peta citra, peta sarana dan prasarana, serta peta penutup lahan dan penggunaan lahan (Badan Informasi Geospasial, 2018). Program ini dilakukan berdasarkan hasil observasi lapangan yang menunjukkan bahwa 
kurangnya gambaran yang informatif mengenai peta Desa Fatusene. Berdasarkan prioritas pemilihan kegiatan. Peta desa tentunya bertujuan untuk memberikan informasi yang informatif mengenai Desa Fatusene. Seperti, batasbatas wilayah, letak sekolah, letak mata air. Kegiatan menggambar peta desa ini dilakukan di Kantor Desa dan di penginapan. Proses menggambar ini menggunakan media software editing (autocad, photoshop) dan telah mendapatkan persetujuan dari aparat pemerintah Desa Fatusene (Gambar 7).

Program kerja pembuatan papan stuktur desa dipilih dan ditetapkan dalam rencana kerja berdasarkan hasil observasi lapangan dan telah disetujui oleh aparat Desa. Program ini dilaksanakan dari tanggal 23 Agustus 2019 sampai dengan 02 September 2019. Program ini dimulai dengan persiapan alat dan bahan, print huruf kemudian mendesain (pemotongan huruf), pemotongan huruf dan pilox huruf. Dilanjutkan dengan print nama-nama staf Desa kemudian digunting dan ditempel. Kemudian menggambar garis komando dan garis koordinasi pada papan struktur yang sudah tersedia lalu pemasangan papan garis struktur di Kantor Desa. Program ini bertujuan untuk melengkapi administrasi yang ada di kantor Desa Fatusene, seperti yang terlihat pada Gambar 8.

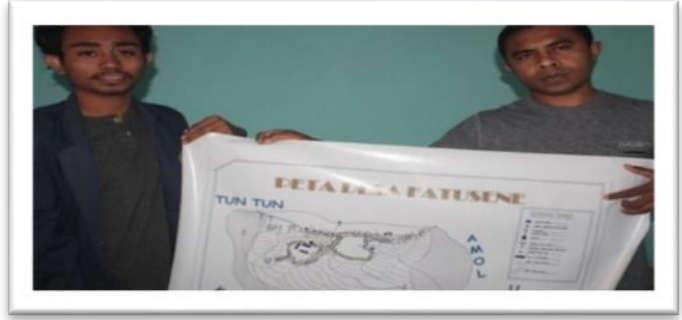

Gambar 7. Pembuatan Peta Desa dan Hasil Peta Desa Fatusene

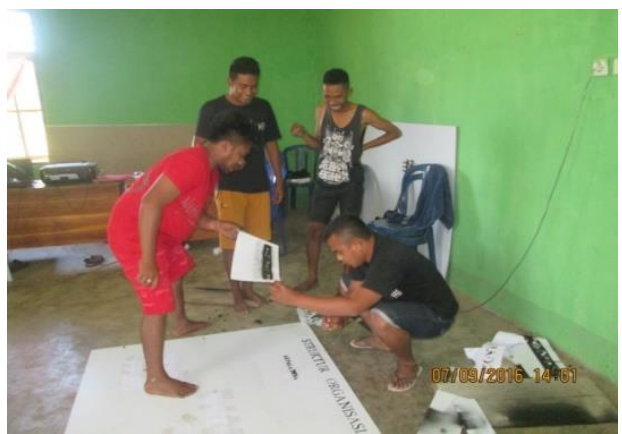

Gambar 8. Pembuatan Papan Struktur Desa

Sosialisasi tentang menabung dini bagi anak dan remaja Desa Fatusene.
Pendidikan keuangan sangat penting bagi semua kalangan usia, khususnya anakanak. Pendidikan tentang bagaimana cara mengelola keuangan secara bijak sesuai dengan kebutuhan. Edukasi tentang mengelola uang dengan baik harus dimulai sejak usia dini khususnya anak pra sekolah dan anak usia sekolah dasar (Sadri, 2019). Menabung saat ini merupakan hal yang penting, di mana sudah mulai ditanamkan sejak dini oleh orang tua kepada anaknya. Karena tabungan memilki peranan penting di masa depan, yang berarti menyisihkan sebagian uang yang dimiliki untuk disimpan (Abdillah Mundir, 2018). Oleh karena itu menabung yang paling mudah adalah di rumah karena dapat dilakukan setiap waktu. Kegiatan ini bertujuan untuk menumbuhkan pemahaman dan kesadaran menabung dan berinvestasi bagi anak dan remaja, agar terbiasa menabung dan menjadikannya suatu kebiasaan positif sampai saat dewasa nantinya. Pada kegiatan ini dilakukan sosialisasi tentang pentingnya menabung usia dini dan menjelaskan manfaat dari menabung pada usia dini sehingga dapat memotivasi anak dalam menabung (Gambar 9). Kegiatan ini dilakukan anak-anak SDN Fatusene dan remaja Desa Fatusene.

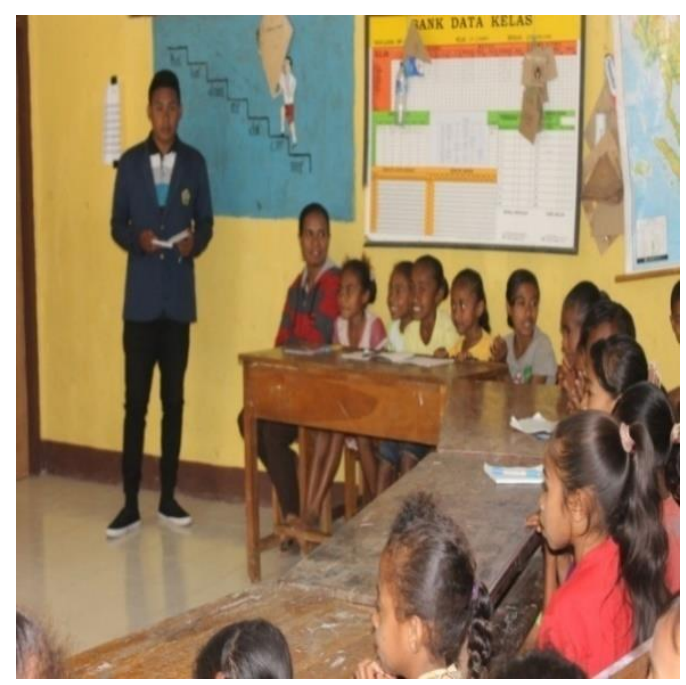

Gambar 9. Sosialisasi Menabung Dini Bagi Anak Dan Remaja

\section{SIMPULAN DAN SARAN Simpulan}

Pelaksanaan kegiatan KKN dapat terlaksana secara baik, bermanfaat, dan memberi dampak yang positif pada masyarakat karena berbagai kegiatan yang dilakukan berkorelasi dengan permasalahan yang ada pada masyarakat sehingga menimbulkan adanya respon yang baik dan partisipasi aktif 
dari masyarakat dan aparat Desa Fatusene.

\section{Saran}

Diharapkan adanya kegiatan-kegiatan lanjutan melalui berbagai program kemitraan yang menindaklanjuti hasil kegiatan ini dan juga memecahkan berbagai persoalan lain yang ada, dengan tetap mengedepankan partisipasi aktif masyarakat dam pemerintah Desa Fatusene.

\section{UCAPAN TERIMAKASIH}

Terima kasih kepada LPPM

Universitas Nusa Cendana yang telah mendukung kegiatan ini, teman-teman dosen dan mahasiswa yang telah membantu sehingga kegiatan pengabdian kepada masyarakat ini bisa terlaksana dengan lancar hingga selesai.

\section{DAFTAR RUJUKAN}

Abdillah Mundir (2018) 'Penerapan Pendidikan Financial Pada Anak Usia Sekolah', journal AL-MUDARRIS, 1(2), pp. 108120. Available at: http://ejournal.staima-alhikam.ac.id.

Badan Informasi Geospasial (2018) 'Peraturan Kepala Badan Informasi Geospasial Nomor 3 Tahun 2016 tentang Spesifikasi Teknis Penyajian Peta Desa', in Peraturan BIG, pp. 1-8.

Badan Pusat Statistik (2015) 'Timor Tengah Utara dalam Angka', BPS Provinsi Nusa Tenggara Timur, p. 577.

Badan Pusat Statistik (2018) 'Kecamatan Miomaffo Timur Dalam Angka', BPS Kabupaten TTU.

Dirjen Pendidikan Tinggi, (2013) 'Panduan Penelitian dan Pengabdian Kepada Masyarakat di Perguruan Tinggi', Direktorat Jenderal Pendidikan Tinggi.

Fitriany, E. A. and Abidin, Z. (2020) 'Pengaruh Pupuk Bokashi Terhadap Pertumbuhan Mentimun (Cucumis sativus L.) si Desa Sukawening, Kabupaten Bogor, Jawa Barat', Jurnal Pusat Inovasi Masyarakat (PIM), 2(5), pp. 881-886.

Indarto, I. (2010) Hidrologi -- Dasar Teori dan Contoh Aplikasi Model Hidrologi ( ISBN: 978--979--010--579-9). doi: 10.13140/RG.2.1.3678.9527.

Kemendes, P. (2019) 'Kuliah kerja nyata terintegrasi pembangunan desa 2019'.

Munir, M. (2016) 'Peran Usaha Kecil dan Menengah (UKM ) dalam Penciptaan Lapangan Kerja Baru', Modernisasi, 1(2), pp. 120-127.

Sadri, M. (2019) 'Pemberdayaan Siswa Melalui Edukasi Keuangan Sejak Dini Sebagai Upaya Pembentukan Karakter Cerdas Mengelola Uang', Proseding Seminar
Nasional Kewirausahaan, 1(1), pp. 290-295.

Sukamto, P. S. N. S. (2013) 'Kombinasi Pemberian Vitamin A Dan E Dalam Ransum Terhadap Kecernaan Lemak Dan Indikator Ketahanan Tubuh Pada Ayam Kedu Petelur', 2(1), pp. 385-392. 